\title{
The Performance of Continuous Rotifer (Brachionus Plicatilis) Culture System for Ornamental Fish Production
}

\author{
Umur Önal, Gözen Topaloğlu and Ahmet Sepil \\ Çanakkale Onsekiz Mart University, Faculty of Marine Sciences and Technology, Terzioğlu Campus, Çanakkale 17100, Turkey
}

Received: May 3, 2015 / Accepted: May 7, 2015 / Published: May 30, 2015.

\begin{abstract}
Rotifers are considered as one of the most important prey organisms in the culture of altricial fish larvae. However, high density rotifer culture is often problematic due to water quality problems which results in frequent crashes. In the present study, the performance of a small-scale, continuous system was evaluated for culturing rotifers, Brachionus plicatilis, using concentrated nonviable green algae, Nannochloropsis oculeataas feed in a $160 \mathrm{~L}$ tank for a period of 90 days. The system configuration was simple and major components consisted of a protein skimmer and a pure oxygen delivery system. Although egg ratio increased from $3 \%$ on day 1 to $21.8 \%$ and $39.3 \%$ on days 7 and 9 , respectively, rotifer growth was slow at start up and resulted in fluctuations in total number of rotifers between days 19-41. Rotifer densities remained $<400$ until day 51 but increased at higher rates reaching 900 individuals $/ \mathrm{mL}$ on day $55,1,620$ on day 60 and 2,127 on day 70 . Rotifer density reached a maximum of 2,188 individuals $/ \mathrm{mL}$ on day 85. Once the rotifer density exceeded 1,500 individuals $/ \mathrm{mL}$ (day 60), periodical harvesting (a total of 16 harvest events) produced a total of $369,920,000$ rotifers corresponding to a daily production of 12,330,667 individuals/day during the next 30 days until the experiment was terminated at day 90 . As a result of periodic harvesting, water makeup and continuous protein skimming, total settleable solids and $\mathrm{NH}_{3}-\mathrm{N}$ levels remained low and ranged between $4-22 \mathrm{~mL} / \mathrm{L}$ and $0.4-2.2 \mathrm{mg} / \mathrm{L}$, respectively. The authors' findings indicated that this inexpensive culture system can be successfully used for small-scale marine or freshwater ornamental fish production. Further work is required to minimize lag period at start-up and increase the production potential and yield by better management of suspended solids.
\end{abstract}

Key words: Rotifer, Brachionusplicatilis, high-density culture, continuous systems, concentrated algae.

\section{Introduction}

A major bottleneck in production of altricial finfish larvae is inadequate nutrition during early stages. In spite of improvements in microparticulate diet technology, exclusive use of formulated diets is problematic and currently, feeding larval fish with live food organisms during earlier stages results in higher growth and survival rates. The brackish water rotifer, Brachionusplicatilis, is one of the most important live food organisms that are extensively used for the larval culture of most altricial ornamental marine and

\footnotetext{
Corresponding author: Ahmet Sepil, Ph.D. student, research field: larval fish culture. E-mail: ahmetsepil@outlook.com.
}

freshwater fish all over the world. As a result, there are considerable efforts towards developing reliable technology for the sustainable culture of rotifers [1].

In commercial food fish aquaculture, rotifers are extensively cultured using baker's yeast or other yeast-based products in batch systems to minimize negative effects of poor water quality. Batch systems are characterized by harvesting all rotifers once a predetermined density level is reached usually within couple of days after start up. In batch systems, rotifer densities rarely exceed 500-1000 individuals/mL [2, 3] and higher densities are subject to sudden crashes due to poor water quality requiring the use of backup systems which in turn increase production costs $[4,5]$. Due to limitations of batch systems, high-density 
systems have been developed particularly for the culture of marine food fish larvae to meet the increasing demands of rotifers during early stages. Densities up to $2 \times 10^{4}-1.6 \times 10^{5}$ rotifers $/ \mathrm{mL}$ have been reported from high-density and ultra-high density systems [5-9]. However, very high levels of unionized ammonia $\left(\mathrm{NH}_{3}-\mathrm{N}\right)$ and solids, foam formation and proliferation of pathogenic bacteria are major problems in such high-density cultures and require complex and expensive approaches for their removal. For example, in high density systems, optimum water quality is maintained by continuous recirculation where culture water is reconditioned through a series of physical, biological and chemical filters [5] often requiring the need for specialized and trained personnel. On the other hand, demand of rotifer in ornamental fish culture is merely a fraction of that required for marine food fish culture and therefore, the need for complex and expensive rotifer systems may not be justified. Hence, there is a need to develop cost-effective, reliable and simple systems that can provide rotifers for small-scale ornamental fish production on a daily basis.

The aim of the present study is to test the production performance of a small-scale continuous, high-density rotifer culture system. A further goal of the study is to develop a cost-effective and simple system that can be operated easily. This system, then, can be used for small-scale rotifer production to meet demands of early altricial fish larvae of many different marine or ornamental fish species.

\section{Materials and Methods}

\subsection{General System Configuration}

The general system set up was similar to that described earlier for producing rotifers for marine food fish (Fig. 1) [10]. Briefly a cylindro-conical tank with an operational volume of $160 \mathrm{~L}$ was used. Water temperature throughout the experiment was maintained at $25 \pm 2{ }^{\circ} \mathrm{C}$ using submersed heaters. Salinity was adjusted to $24 \pm 2$ ppt throughout the experiment. Pure oxygen was supplied from a pressurized tank in order to maintain adequate dissolved oxygen concentrations under high rotifer densities. Additional aeration was also provided to maintain homogeneous distribution of rotifers and algae in the water column. In order to reduce the accumulation of organic material custom made protein skimmer was used. In addition, periodic water exchanges reduced the TSS (total settleable solids) concentrations to less than $50 \mathrm{~mL} / \mathrm{L}$ which is critical for the routine maintenance of the system [10].

\subsection{Water Quality}

While temperature was measured daily, $\mathrm{DO}, \mathrm{pH}$ and $\mathrm{NH}_{3}-\mathrm{N}$ concentrations were measured periodically. $\mathrm{NH}_{3}-\mathrm{N}$ levels were measured on water samples (20-100 mL) that were filtered through a GF/F filter $(0.45 \mu \mathrm{m})$ using a colorimeter (Hach DR 890, USA).

TSS concentrations were measured volumetrically using an Imhoff cone [10]. Briefly, a 1 L sample from the rotifer tank was settled for $45 \mathrm{~min}$, followed by gentle stirring the sides of cone with a glass rod. The sample was then allowed to settle for another $15 \mathrm{~min}$ and the volume of settleable solids was recorded as $\mathrm{mL}$ per liter.

\subsection{Rotifer Stock and Feeding}

Brachionusplicatilis stock was obtained from Akuatek Su Ürünleri A.Ş. (Şakran, İzmir, Turkey) that was previously batch cultured using a mixture of baker's yeast and algae.

Concentrated Nannochloropsis oculeata (Reed Mariculture, USA) was used as the rotifer food. One $\mathrm{ml}$ of the concentrated algae contains $6.8 \times 10^{10}$ cell $/ \mathrm{mL}$. The mean feeding rate was $1 \mathrm{~mL}$ for 1.5 million rotifers and was administered using an automatic dispenser.

\subsection{Rotifer Density}

Since the initial water volume in the culture tank $(20 \mathrm{~L})$ was increased steadily in order to accommodate 


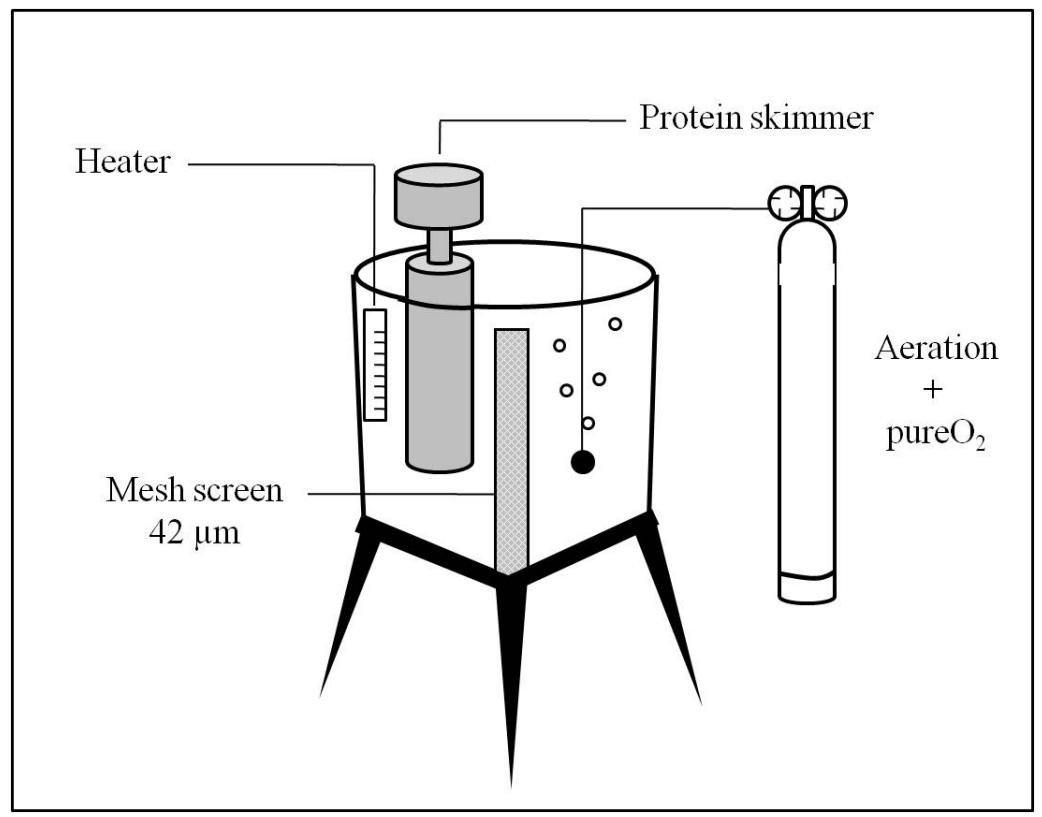

Fig. 1 General configuration of rotifer culture system.

the growing population of rotifers (final volume 160 L), increases in rotifer density do not reflect the overall status of the culture until after 52th day when the culture volume reached to its maximum level of $160 \mathrm{~L}$. Rotifer densities were obtained from the mean of duplicate samples $(1 \mathrm{~mL})$ taken from the culture unit. A third sample was taken if there was $>10 \%$ difference between the first 2 samples. Rotifers were fixed using a lugol solution before counting and counted under a light microscope. The number of females carrying eggs was also counted and reported as the egg ratio. The rotifers were harvested periodically starting at day 60 and a total of 16 harvests were performed until the experiment was terminated on day 90. After each harvest rotifer density in the culture tank was reduced to 1,500 individuals $/ \mathrm{mL}$ (day 60-61), 1,700 individuals $/ \mathrm{mL}$ (day 63-66), 1,800 individuals/mL (day 70-83) and 2,000 individuals $/ \mathrm{mL}$ (day 85-89) in order to increase the production capacity of culture tank. The experiment was terminated at day 90 when all concentrated algae stock was used.

SGR (specific growth rate) was calculated using equation [12].

$$
\mathrm{SBH}=\left(\ln \mathrm{N}_{\mathrm{t}^{-}} \ln \mathrm{N}_{0}\right) / \mathrm{t}
$$

where $\mathrm{N}_{0}$ initial rotifer concentration; $\mathrm{N}_{t}$, rotifer concentration at time $\mathrm{t} ; \mathrm{t}$ culture period (days).

\section{Results}

\subsection{Water Quality}

The temperature ranged between 21.6-27.0 ${ }^{\circ} \mathrm{C}$ throughout the experimental period (March-June 2010) due to increases in ambient temperatures as the season progressed from spring to early summer. However, the use of submerged heaters prevented temperature fluctuations and daily variation never exceeded $\pm 1{ }^{\circ} \mathrm{C}$. Oxygen levels were fairly constant (8.5-10.2 ppm) and $\mathrm{pH}$ values varied between 7.54-8.10 during experimental period. $\mathrm{NH}_{3}-\mathrm{N}$ and TSS concentrations fluctuated and ranged between $0.4-2.2 \mathrm{mg} / \mathrm{L}$ and 4-22 $\mathrm{mL} / \mathrm{L}$, respectively. The gradual increase of $\mathrm{NH}_{3}-\mathrm{N}$ and TSS were associated with increased feeding rates but periodic water exchanges $(1-5$ L) prevented excessive accumulation.

\subsection{Rotifer Culture}

Fig. 2 shows the changes in rotifer density during the experiment. The maximum rotifer density was 2,188 individuals $/ \mathrm{mL}$ on day 85 . The maximum number of individuals bearing eggs was $46.4 \%$ on day 
53 and the egg ratios were never below $37.4 \%$ after day 43. During the first ten days of the experiment, rotifer density remained low $(<100$ individuals $/ \mathrm{mL})$ due possibly, to transport stress. The egg ratio was also lower during the first week $(<6 \%)$ but increased on day 7 and 8 , reaching to $21.8 \%$ and $38.6 \%$, respectively. Rotifer density showed a steady increase afterwards and reached 180 individuals $/ \mathrm{mL}$ on day 13 . The initial water volume in the culture tank $(20 \mathrm{~L})$ was also increased steadily to accommodate the growing population of rotifers reaching $30 \mathrm{~L}$ in day $9,50 \mathrm{~L}$ in day $26,90 \mathrm{~L}$ in day $34,130 \mathrm{~L}$ in day 42 and $160 \mathrm{~L}$ on day 52. Therefore, total rotifer number rather than rotifer density was a better indication of the status of the culture until day 52. Rotifer densities remained $<$
300 until day 48 and $<400$ until day 50, but increased at higher rates reaching 900 individuals $/ \mathrm{mL}$ on day 55 , 1,620 on day 60 and 2,127 on day 70 . Rotifer density reached a maximum of 2,188 individuals $/ \mathrm{mL}$ on day 85. There were no significant correlations between the rotifer density and egg ratio throughout the experimental period and the rotifer density kept increasing irrespective of the changes in egg ratio reaching 1,620 individuals $/ \mathrm{mL}$ on day 60 . Periodical harvesting started on day 60 and a total of 16 harvests yielded $341,760,000$ rotifers at the end of day 90 (total of 30 days), corresponding to a mean of $11,392,000$ rotifers/day. The minimum and maximum specific growth rates ranged between 0.01 (day 14) and 0.53 (day 35), respectively.

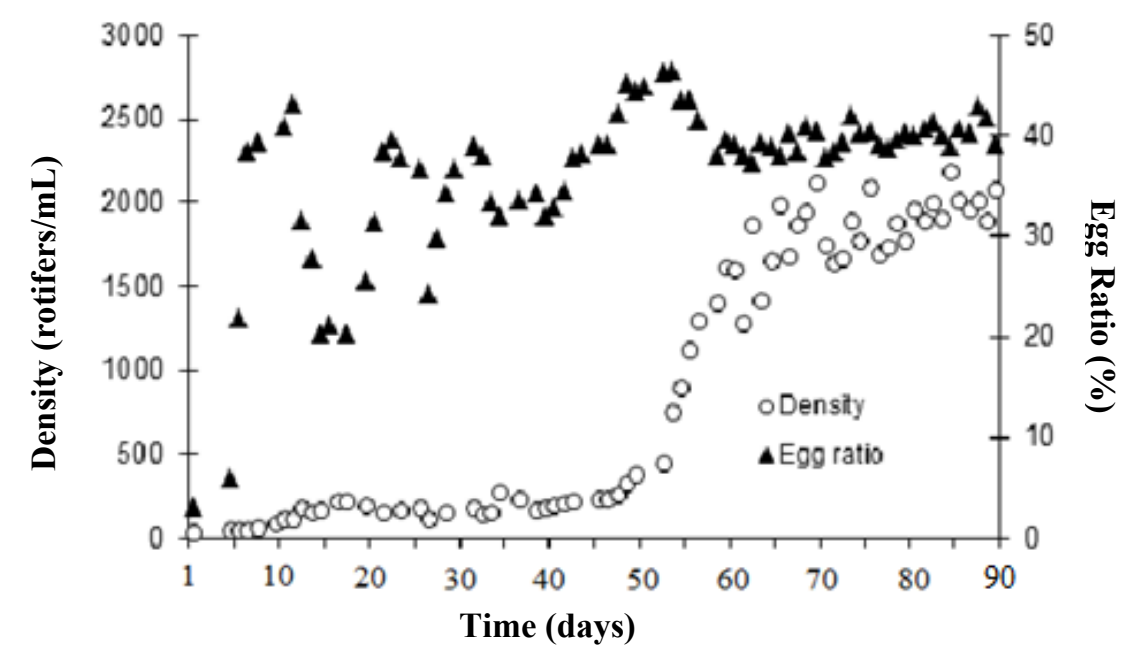

Fig. 2 Daily changes in rotifer density and egg ratio during experiment.

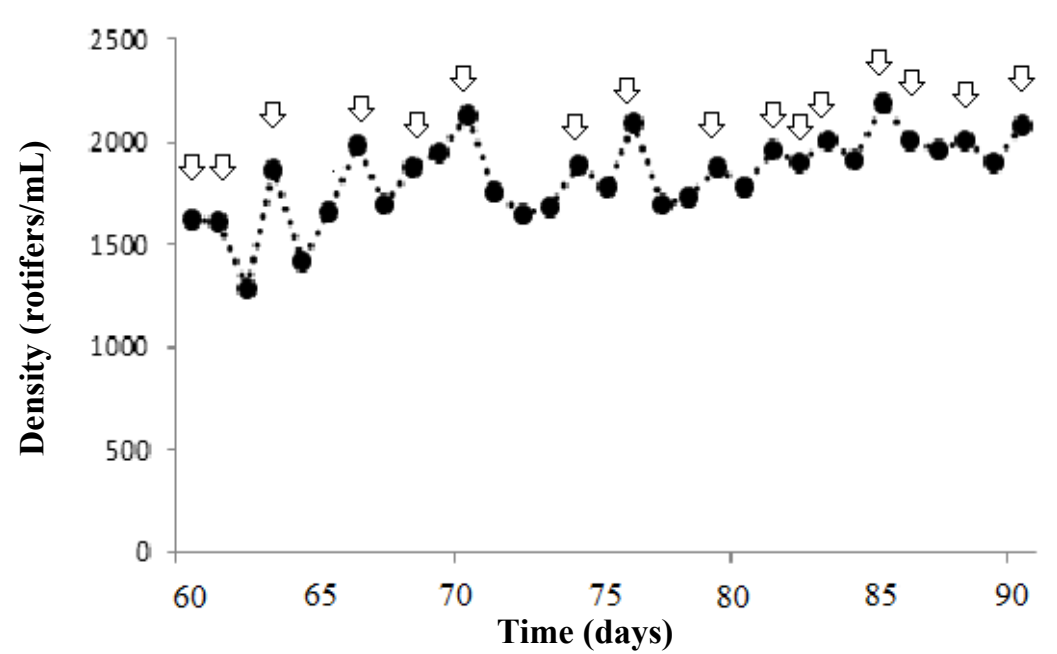

Fig. 3 Daily changes in rotifer density and egg ratio between day 60-90. Arrows indicate harvest time. 


\section{Discussion}

In the present study, a small-scale continuous culture of the rotifer, Brachionusplicatilis, using concentrated algae was maintained for a period of 90 days and produced a mean of 12,330,667 rotifers/day for 30 days between start of harvesting on day 60 up until day 90 when the experiment was terminated. Although the maximum density in the present study $(2,188$ individuals $/ \mathrm{mL})$ was less than that reported in a similar set up [10], the experimental period was longer (18 vs. 90 days) with a total of 16 harvest events and showed the effects of frequent harvesting on culture stability. During the experimental period, rotifer density increased slowly during the first 50 days followed by a higher increase until day 70 after which population density was stable and did not crash. This finding is in contrast to others that used baker's yeast or other commercial yeast-based products for rotifer culture and reported frequent crashes of rotifer populations [5, 7] and indicates the suitability of nonviable, concentrated algae for culturing rotifers. In addition, although all reported high-density rotifer systems employed expensive and complicated set-ups or additional equipments for recirculation $[1,3,5,7,9$, $13,14]$, the design of the present system was simple and inexpensive with only a protein skimmer placed inside the tank and a pressurized pure $\mathrm{O}_{2}$ tank.

Egg ratio is a good indication of the general health and status of rotifer populations and may help to predict culture density on a daily basis [10]. In the present study, egg ratio ranged between a minimum of $6 \%$ during the initial culture period to a maximum of $46.23 \%$ on day 54 . Lower egg ratios are typical during start up and may be related to transport stress and former culture conditions. However, the reasons for the dramatic decrease in egg ratios from $43.1 \%$ on day 12 to $20.4 \%$ on day 15 is not known, but resulted in an extended lag phase that lasted until day 43-44. Higher egg ratios (mean $43.3 \pm 2.7 \%$ ) between day 44-56 coincided with rotifer densities reaching from 220 individuals/ml on day 43 to 1,129 on day 56 . Egg ratios were relatively stable after day 59 until day 90 with a mean of $39.9 \pm 1.4 \%$. This ratio was slightly higher than that (33-36\%) reported by Önal et al. [10]. Keeping egg ratio above $40 \%$ is desirable as it indicates favorable conditions for rotiferre production [10] and allows predictions on density of rotifers the next day. On the other hand, fluctuations in rotifer concentrations are common and may be unpredictable; for example, Bentley et al. [1] reported no specific causes for declines of rotifer density in a recirculating, continuous system. In the present study, the increase in density of rotifers was slower compared to previous work [10] and indicates the need for better understanding relationships between physico-chemical parameters and rotifer growth.

Maintenance of physico-chemical conditions at optimum levels at high rotifer concentrations is difficult. Several water quality parameters including TSS, $\mathrm{NH}_{3}-\mathrm{N}$ and $\mathrm{pH}$ have been reported to have a significant effect on culture status. Accumulation of organic material has been reported to be an important factor that increases $\mathrm{NH}_{3}-\mathrm{N}$ concentration and interferes with rotifer feeding $[15,16]$. Considerable efforts have been spent towards reducing and removal of TSS $[5,9,16]$. Use of filtration mats have been previously described for high-density cultures and reported to be effective by removing up to $80 \%$ of solids substances and contaminating protozoans such as Vorticella [1, 15]. However, our previous work indicated that filtration mats remove a significant amount of rotifers from the water column and require the need for frequent cleaning [10]. In the present study, the accumulation of TSS was not a major problem limiting rotifer reproduction due to the use of a protein skimmer and frequent flushes. Analysis of the foam discharged from the skimmer did not indicate significant rotifer removal from the culture tank and justified its effective use in rotifer culture. The maintenance routine described in the present study prevented detritus build up, eliminated periodic 
tank cleaning and rotifer restocking and therefore, reduced labor. In previous studies, periodic tank cleaning and rotifer restocking have been used as an effective way to reduce TSS build up [1, 10]. Developing cost effective and practical filtration methods that effectively remove TSS is of considerable importance for successful high density cultures and further work is required to test their potential for long term ( $>90$ days) management.

Although regular $\mathrm{NH}_{3}-\mathrm{N}$ measurements have not been performed in the present study, the overall status of rotifers (swimming speed, egg ratio, presence of protozoans, etc.) did not indicate any negative effect of $\mathrm{NH}_{3}-\mathrm{N}$ toxicity. Therefore, no correlation between rotifer density and $\mathrm{NH}_{3}-\mathrm{N}$ was established. Rotifers are known to be resistant to $\mathrm{NH}_{3}-\mathrm{N}$ concentrations although reported levels of toxicity differ. For example, the toxic $\mathrm{LC}_{50}$ concentration of unionized ammonia for marine Brachionus has been reported to be $17.0 \mathrm{mg} / \mathrm{L}$ at $23{ }^{\circ} \mathrm{C}$ during a period of $24 \mathrm{~h}$ [17] and resulted in $50 \%$ lower growth and fecundity compared to treatments that had $7.8 \mathrm{mg} / \mathrm{L}$ and $13.2 \mathrm{mg} / \mathrm{L} \mathrm{NH}_{3}-\mathrm{N}$. In batch-cultures, $\mathrm{NH}_{3}-\mathrm{N}$ concentrations were reported to be the major limiting factor when reached at 10 $\mathrm{mg} / \mathrm{L}$. In contrast, up to $22-34 \times 10^{3}$ rotifers $/ \mathrm{mL}$ were cultured at TAN (total ammonia nitrogen) levels of $1,000 \mathrm{mg} / \mathrm{mL}$ at a $\mathrm{pH}$ level of 7 [15]. In the present study, measured levels of ammonia were much lower than values that were reported to induce stress and ranged between $0.4-2.2 \mathrm{mg} / \mathrm{L}$.

In the present study, a total of $199.3 \mathrm{~L}$ of water was siphoned out of the system and exchanged to reduce TSS and improve water quality during 90 days, corresponding to $124.5 \%$ of the total culture volume $(160 \mathrm{~L})$. The amount of exchanged fresh seawater does not include routine seawater additions during the first 52 days to accommodate increasing rotifer density in the culture tank. However, limited water exchange rates did not affect culture stability especially when rotifer densities reached $>1,000$ individuals $/ \mathrm{mL}$. Although increased rates of water exchange is desired due to its positive effects on accumulation of toxic substances [3, 14] higher flow rates often require specific modifications of culture tank setup in order to handle problems associated with increased water exchange. For example, higher rates of water flow into rotifer culture tank may reduce algae concentration due to dilution and increase the potential of screen clogging. In the present study, use of a protein skimmer reduced the need for water exchange. Although no comparative data was obtained, the use of a protein skimmer has further improved water quality as indicated by the dark-colored, nutrient rich tank water accumulated in the collection cup as a result of foaming.

In summary, the authors' findings support those of others who reported that high-density, continuous culture of rotifers using concentrated algae may help to solve major problems that commonly occur in traditional, batch-culture systems using yeast-based products [5]. However, in order to culture rotifers at high densities in a small-scale for extended periods, complicated and expensive setups are not necessary. A cost-effective, small-scale system can successfully be operated for a period of 90 days without the need of expensive control systems and filtration equipments. Although further research is required to control and fine-tune harvesting periodicity and the changes in physico-chemical parameters, the authors' results indicated that a consistent rotifer culture system can be achieved with very limited water exchange rates and densities up to 2,000 individuals $/ \mathrm{mL}$ can be maintained. Such simple systems can easily meet the demands of early larvae in the production of small-scale ornamental marine and freshwater fish species.

\section{Acknowledgments}

The authors thank Reed Mariculture (USA) for supplying concentrated microalgae.

\section{References}

[1] Bentley, C. D., Carroll, P. M., and Watanabe, W. O. 2008. 

System for Ornamental Fish Production

"Intensive Rotifer Production in a Pilot-Scale Continuous Culture Recirculating System Using Nonviable Microalgae as an Ammonia Neutralizer." Journal of the World Aquaculture Society 39 (5): 625-35.

[2] Morizane, T. 1991. "A Review of Automation and Mechanization Used in the Production of Rotifers in Japan.” In Proceedings of the US-Asia Workshop,79-88.

[3] Suantika, G., Dhert, P., Nurhudah, M., and Sorgeloos, P. 2000. "High-Density Production of the Rotifer Brachionusplicatilis in a Recirculating System: Consideration of Water Quality, Zootechnical and Nutritional Aspects." Aquacultural Engineering 21: 201-14.

[4] Candreva, P., Dhert, P., Novelli, A., and Brissi, D. 1996. "Potential Gains through Alimentation/Nutrition Improvements in the Hatchery." In: Chatain, B. et al. (Ed.). Seabass and seabream culture: problems and prospects: handbook of contributions and short communications presented at the International Workshop on "Seabass and seabream culture: problems and prospects" Verona, Italy, pp. 149-59.

[5] Suantika, G., Dhert, P., Sweetman, E., O'Brien, E., and Sorgeloos, P. 2003. "Technical and Economical Feasibility of a Rotifer Recirculation System." Aquaculture 227: 173-89.

[6] Suantika, G., Dhert, P., Rombaut, G., Vandenberghe, J., De Wolf, T., and Sorgeloos, P. 2001. "The Use of Ozone in a High Density Recirculation System for Rotifers." Aquaculture 201 (1): 35-49.

[7] Dhert, P., Rombaut, G., Suantika, G., and Sorgeloos, P. 2001. "Advancement of Rotifer Culture and Manipulation Techniques in Europe.” Aquaculture 200: 129-46.

[8] Hagiwara, A., Gallardo, W. G., Assavaaree, M., Kotani, T., and Araujo, A. B. 2001. "Live Food Production in Japan: Recent Progress and Future Aspects." Aquaculture 200: 111-27.

[9] Yoshimura, K., Tanaka, K., and Yoshimatsu, T. 2003. “A
Novel Culture System for the Ultra-High Density Production of the Rotifer, Brachionus rotundiformis - a Preliminary Report.” Aquaculture 227: 165-72.

[10] Önal, U., Çelik, I., and Ergün, S. 2010. "The Performance of a Small-Scale, High-Density, Continuous System for Culturing the Rotifer Brachionus Plicatilis." Turkish Journal of Veterinary and Animal Sciences 34: 187-95.

[11] APHA (American Public Health Association). 1985. Standard Methods for the Examination of Water and Waste Water. Washington, DC: APHA.

[12] Øie, G., Reitan, K. I., and Olsen, Y. 1994. "Comparison of Rotifer Culture Quality with Yeast Plus Oil and Algal-Based Cultivation Diets." Aquaculture International 2: 225-38.

[13] Rombaut, G., Grommen, R., Zizhong, Q., Vanhoof, V., Suantika, G., Dhert, P., and Verstraete, W. 2003. "Improved Performance of an İntensive Rotifer Culture System by Using a Nitrifying İnoculum (ABIL)." Aquaculture Research 34 (2): 165-74.

[14] Fu, Y., Hada, A., Yamashita, T., Yoshida, Y., and Hino, A. 1997. "Development of a Continuous Culture System for Stable Mass Production of the Marine Rotifer Brachionus." Hydrobiologia 358: 145-51.

[15] Yoshimura, K., Hagiwara, A., Yoshimatsu, T., and Kitajima, C. 1996. "Culture Technology of Marine Rotifers and the Implications for Intensive Culture of Marine Fish in JAPAN." Mar. Freshwater Res. 47: 217-22.

[16] Yoshimura, K., Usuki, K., Yoshimatsu, T., Kitajima, C., and Hagiware, A. 1997. "Recent Development of a High Density Mass Culture System for the Rotifer Brachionus rotundiformis Tschugunoff." Hydrobiologia 358: 139-44.

[17] Yu, J. P., and Hirayama, K. 1986. "The Effect of Un-ionized Ammonia on the Population Growth of the Rotifer in Mass Culture." Nippon Suisan Gakkaishi 52: 1509-13. 